\title{
Effect of Training at Lactate Threshold Intensity on Maximal Time to Exhaustion, Depression and Anxiety Behaviour of Spontane- ously Hypertensive Rats after Kainate-Induced Status Epilepticus
}

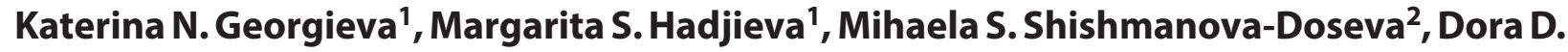 \\ Terzieva ${ }^{3}$, Nikola G. Georgiev ${ }^{4}$, Georgi G. Andreev ${ }^{4}$, Jana D. Tchekalarova ${ }^{5}$ \\ ${ }^{1}$ Department of Physiology, Faculty of Medicine, Medical University of Plovdiv, Plovdiv, Bulgaria \\ 2 Department of Pharmacology and Drug Toxicology, Faculty of Pharmacy, Medical University of Plovdiv, Plovdiv, Bulgaria \\ ${ }^{3}$ Department of Clinical Laboratory, Faculty of Pharmacy, Medical University of Plovdiv, Plovdiv, Bulgaria \\ ${ }^{4}$ Faculty of Medicine, Medical University of Plovdiv, Plovdiv, Bulgaria \\ ${ }^{5}$ Institute of Neurobiology, BAS, Sofia, Bulgaria
}

\section{Correspondence:}

Katerina N. Georgieva, Department of Physiology, Medical University of Plovdiv, 15A Vassil Aprilov Blvd., 4002 Plovdiv, Bulgaria

E-mail:kng@plov.net

Tel: +359898 774527

Received: 16 Oct 2015

Accepted: 21 July 2016

Published Online: 29 Nov 2016

Published: 27 March 2017

Key words: treadmill training, status epilepticus, anxiety, SHRs

Citation: Georgieva KN, Hadjieva MS, Doseva MS, Terzieva DD, Georgiev NG, Andreev GG, Tchekalarova JD. Effect of training at lactate threshold intensity on maximal time to exhaustion, depression and anxiety behaviour of spontaneously hypertensive rats after kainate-induced status epilepticus.

Folia Medica 2017;59(1):91-97. doi: 10.1515/folmed-2017-0004
Aim: The objective of the present study was to investigate the effect of treadmill training at lactate threshold intensity on maximum time to exhaustion (MTE) and heart rate (HR) as well as behavioral changes after kainate (KA)-induced status epilepticus (SE) of spontaneously hypertensive rats (SHRs).

Materials and methods: Male SHRs were divided in four groups: two sedentary (vehicle- and KA-treated) and two exercised (vehicle- and KA-treated), respectively. The exercised rats were trained on a treadmill at a speed of $20 \mathrm{~m} \cdot \mathrm{min}^{-1}$ and $0^{\circ}$ elevation for $40 \mathrm{~min}^{-1} \mathrm{~d}^{-1}$, for $4 \mathrm{wk}$. Maximal time to exhaustion and HR was measured at the beginning and at the end of the training period. Status epilepticus was evoked in half of the sedentary and trained rats by a repetitive intraperitoneal injection of KA in low subconvulsive doses. The other half of the groups received saline. Sucrose preference test (SPT) for depression-like behavior and hole board test (HBT) for impulsivity were performed a month after KA/veh injection.

Results: The maximum time of exhaustion was elongated in the SHRs at the end of the training period in comparison with the beginning. However, no effect on $\mathrm{HR}$ was detected in trained rats. Kainate treatment after one month of training alleviated the SE-induced anhedonia in SPT and stereotyped behavior in HBT, respectively.

Conclusions: Taken together, these results demonstrate that exercise exerts a beneficial influence on physical working capacity, depression and impulsive behavior in a co-morbid model of essential hypertension and SE.

\section{INTRODUCTION}

While antihypertensive drugs are considered a first choice of treatment of cardiovascular and renal disease, alternative approaches as aerobic exercise have also been proposed as these have shown beneficial potential in the treatment and prevention of hypertension. Experimental and clinical studies have demonstrated the ability of exercise to provoke beneficial changes in the cardiovascular system of both hypertensive animals and humans. ${ }^{1}$ Many of these studies reported that aerobic exercise has a low risk in patients with hypertension and is associated with positive outcomes, particularly in reducing the arterial blood pressure associated with a considerable decrease in cardiac output. ${ }^{2}$ Aerobic exercise has been found to reduce significantly the mean systolic and diastolic blood pressure in both normotensive and hypertensive persons. ${ }^{2}$ Similar results have been observed in spontaneously hypertensive rats (SHRs) which are considered to be a relevant model of essential hypertension. ${ }^{3}$

Physical exercise is recommended as a nonpharmacological treatment for a series of diseases, including co-morbid hypertension and epilepsy. 
Endurance training leads to a variety of adaptation processes in the organism which not only improve aerobic working capacity but also has neuroprotective effects. Chronic hypertensive state results in a decreased seizure threshold both in humans ${ }^{4}$ and SHRs $^{5}$. Moreover, neuronal damage in the hippocampus, neurochemical and behavioral changes ${ }^{6}$ suggest that SHRs may be validated as a model of co-morbid hypertension and epilepsy. Our previous studies have shown that SHRs are characterized by a higher seizure susceptibility and more vigorous changes in behavior compared to normotensive Wistar rats during the chronic phase in kainate (KA) model of temporal lobe epilepsy. ${ }^{7,8}$ Moreover, recently we reported that long-term training mitigated epileptogenesis and deleterious behavioral changes whose beneficial effects were accompanied by an enhancement of the hippocampal 5-HT release in SHRs. ${ }^{9}$

\section{AIM}

The aim of the present study was to investigate further the effect of endurance training at lactate threshold intensity on maximal time to exhaustion, heart rate and KA-induced behavioral changes in SHRs.

\section{MATERIALS AND METHODS}

Male spontaneously hypertensive rats (200-250 g) were used in this study. Animals were housed in groups of three or four, fed standard rat chow and given water ad libitum and maintained at temperature of $21-24^{\circ} \mathrm{C}$ with $12 / 12 \mathrm{~h}$ dark-light cycle. The procedures used in this study were performed in accordance with the European Communities Council Directive 2010/63/EU. The experimental protocol was approved by the Ethical Committee on Human and Animal Experimentation, Medical University Plovdiv and the Institutional Ethics Committee at the Institute of Neurobiology, Bulgarian Academy of Sciences.

Before KA-induced status epilepticus (SE), the rats were randomly divided into sedentary and 4-week treadmill trained. After the training period, SE was induced in half of the sedentary and trained rats and the other half of the groups received saline. Thus, four experimental groups were formed: sedentary vehicle-treated control (Sed-veh) $(\mathrm{n}=10)$; sedentary control treated with KA (Sed-KA) $(\mathrm{n}=13)$; trained vehicle-treated control (Ex-veh) $(n=10)$; trained treated with KA (Ex-KA) $(\mathrm{n}=12)$.

\section{TRAINING PROCEDURE}

As running on a treadmill is a skilled activity for rats, all of them were exercised on the treadmill (Columbus Instruments, Columbus, USA) at a speed of $20 \mathrm{~m} \cdot \mathrm{min}^{-1}$ and $0^{\circ}$ elevation for $5 \mathrm{~min} \cdot \mathrm{d}^{-1}, 3$ d.wk ${ }^{-1}$ for a 2 weeks before the experiment. Such training duration induces no training adaptations ${ }^{10}$, but familiarizes the rats with treadmill running and allows selection of animals that run spontaneously. Compliant rats were trained on the treadmill at a speed of $20 \mathrm{~m} \cdot \mathrm{min}^{-1}$ and $0^{\circ}$ elevation, for $40 \mathrm{~min} \cdot \mathrm{d}^{-1}$, $5 \mathrm{~d} \mathrm{wk}^{-1}$ for 4 weeks. The duration of the exercise was 20 min on the first day and was increased by 5 min every day. At 5 days it was $40 \mathrm{~min}$ and remained thus until the end of the training period. The sedentary rats were handled every day and 3 d. $\mathrm{wk}^{-1}$ were submitted to a 5-min training at the same speed and elevation to ensure familiarization with treadmill running. The exercise intensity was set according to the maximal lactate steady state during treadmill running, previously identified in SHRs of the same age and weight. ${ }^{11}$ At the end of the training period the sedentary and the trained rats were randomly subdivided into controls (Sed-veh and Ex-veh) and treated with KA (Sed-KA and Ex-KA).

MAXimum time to EXHAUSTION ASSESSMENT

Before and after training, all SHRs were subjected to a test for maximum time to exhaustion (MTE). The test protocol involved a stepwise increase of treadmill speed and elevation, each step being 3 min long. ${ }^{12}$ Rats were removed from the test when they could no longer maintain their position on the treadmill belt. The time taken to reach this stage was assessed as MTE.

\section{HEART RATE MEASUREMENTS}

Heart rate (HR) of trained and sedentary naïve SHRs was measured before the start and after the end of training ( 2 days after the last bout of exercise). It was determined noninvasively in conscious rats by a tail-cuff method using a small animal tail noninvasive blood pressure system (NIBP 200A, Biopac Systems Inc., USA) and MP 150 software for data integration (Biopac Systems Inc., USA). All rats were preheated in a chamber at $37^{\circ} \mathrm{C}$, placed in a restrainer, a cuff was attached to their tail, and pulse frequency was determined using data of arterial blood pressure recordings. For both measurements, the animals underwent a week long adaptation period so as to become familiar with the 
procedure. Except for the first one, the HR value for each rat was registered as the average of at least four measurements.

INDUCTION OF STATUS EPILEPTICUS WITH KAINIC ACID

Kainic acid was diluted in sterile saline $(0.9 \%$ $\mathrm{NaCl})$ at $2.5 \mathrm{mg} \cdot \mathrm{ml}^{-1}$. The protocol of KA-induced SE was executed according to Hellier et al. ${ }^{13}$ with a minor modifcation ${ }^{14}$. Status epilepticus was induced in Sed-KA and Ex-KA groups by repetitive injections of KA (Abcam, UK) starting at a dose of $5 \mathrm{mg} \cdot \mathrm{kg}^{-1}$, i.p. $\left(1 \mathrm{ml} \cdot \mathrm{kg}^{-1}\right)$ at the first hour of observation. Thereafter, KA was delivered in half of the above-mentioned dose every half an hour. Seizure intensity was evaluated by a modified Racine's scale as described previously. ${ }^{14}$ The kainate treatment continued until sustained seizures of class III, IV or V (i.e. $>9$ motor seizures. $\mathrm{h}^{-1}$ ) were observed. The number of motor seizures i.e., classes III, IV and V, were registered and used as criterion for an additional KA injection. Matched controls (Sed-veh and Ex-veh groups) were treated with an equivalent volume and number of saline injections.

\section{SUCROSE PREFERENCE TEST}

The rats were tested for sucrose preference over a three-day period using a two-bottle choice test. On the first day, rats were individually housed and adapted to drink from two identically graduated bottles containing $200 \mathrm{ml}$ of water each. On the following day, rats were trained in the sucrose choice procedure, in which regular water in one of the bottles was replaced with a $1 \%$ sucrose diluted in tap water. On the 3rd (test) day the rats were allowed to drink freely from the two bottles. The test was performed starting from 08:00 a.m. and ran for 24 hours. The bottles were weighed after $12 \mathrm{~h}$ or replaced by a second pair of pre-weighed bottles. The position of the bottles was switched to avoid position preferences. The volume of the sucrose solution consumed as a percentage of the total volume of fluid consumed was calculated during a 12-hour period (light phase - 08:00-20:00 h and dark phase - 20:00-08:00 h).

\section{HOLE BOARD TEST}

The test was performed as described elsewhere. ${ }^{8}$ The hole-board apparatus was made of a gray polystyrene Plexiglas box $(50 \times 50 \times 50)$ with 15 holes 3 $\mathrm{cm}$ in diameter and $1 \mathrm{~cm}$ deep in the floor. Each animal was individually placed in the central area and the number of exploratory head-dipping was recorded for 5 minutes. An increase of the hole- poking response reveals an anxiolytic-like effect. ${ }^{15}$

BRAIN DERIVED NEUROTROPHIC FACTOR DETERMINATION

Decapitation was performed after light anesthesia with $\mathrm{CO}_{2}$ a month after KA-induced SE $(n=8)$. Samples of mixed blood were collected in tubes and centrifuged up to 1 hour after blood collection. Serum was collected and stored at $-20^{\circ} \mathrm{C}$. Serum brain derived neurotrophic factor (BDNF) concentrations were determined using BDNF ELISA kit (CYT306, Merck Millipore). The samples were analyzed in duplicate by Sirio microplate reader (SEAC, Italy) and the mean concentration was accepted as representative for each rat.

\section{STATISTICAL ANALYSIS}

Data are presented as mean \pm SEM. Two-way multivariate ANOVA was performed to analyze the effect of exercise and KA-induced SE (2 independent variables) on different parameters of HBT and the 3rd independent variable was the period of testing (light vs dark phase) in the SPT, respectively. Group differences after significant ANOVAs were measured by post hoc Bonferroni or Holm Sidak test. Paired and independent t-test were applied to analyze heart rate and maximum time to exhaustion. If data were not normally distributed, ANOVA for nonparametric data (Kruskal-Wallis on ranks) followed by the Mann-Whitney U test were used. A $\mathrm{p}<0.05$ value was accepted as indicating statistically significant differences.

\section{RESULTS}

There were no differences in the MTE in the incremental maximal treadmill test between groups at the beginning of the experiment (Fig. 1). The trained rats increased their MTE in comparison with both the baseline values $(\mathrm{p}<0.01)$ and with the sedentary rats $(p<0.01)$ at the end of the training period.

The heart rate of the studied groups was similar at the beginning of the study ( $p>0.05)$. After training no differences in the measured HR were found between trained and sedentary rats $(354.57 \pm 0.61$ beats. $\mathrm{min}^{-1}$ vs. $335.90 \pm 1.17$ beats.min ${ }^{-1}, \mathrm{p}>0.05$ ) and in comparison with the initial values of both groups ( $\mathrm{p}>0.05)$.

For sucrose preference test, three-way ANOVA revealed a main effect of exercise $[\mathrm{F} 1,71=5.225$, $\mathrm{p}=0.025$ ] without interaction between factors. Post hoc test showed higher preference for sweet solutions in the Ex-KA group than in the Sed-KA group during the light and the dark period $(\mathrm{p}<0.05)$ (Fig. 2).

In the HBT, two-way ANOVA demonstrated a 
significant effect of both exercise $[\mathrm{F} 1,38=11.539$, $\mathrm{p}=0.002 ; \mathrm{F} 1,38=14.286, \mathrm{p}=0.001]$ and KA-induced $\mathrm{SE}[\mathrm{F} 1,38=10.341, \mathrm{p}=0.003 ; \mathrm{F} 1,38=9.296, \mathrm{p}<0.004]$ without interaction between the two factors for number and time of head-dipping, respectively. Post hoc test showed a significant increase in the number $(\mathrm{p}<0.03)$ and time $(\mathrm{p}<0.001)$ of head-dipping in the KA-treated rats (Fig. $\mathbf{3 A B}$ ). The long-term training before $\mathrm{SE}$ resulted in a significant decrease in the number $(p<0.002)$ and time $(p<0.001)$ of head-dipping in the KA-treated rats compared to sedentary group.

There was no significant main effect or interaction between training and KA-treatment on the

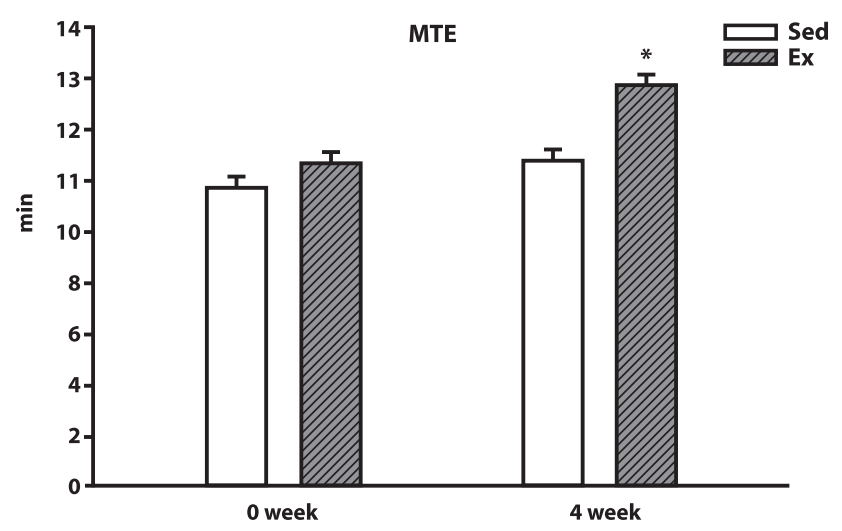

Figure 1. Maximum time to exhaustion (min) of the experimental groups at the beginning and at the end of the training period. $* \mathrm{p}<0.001 \mathrm{vs}$ initial values and vs Sed rats on the 4 th wk.

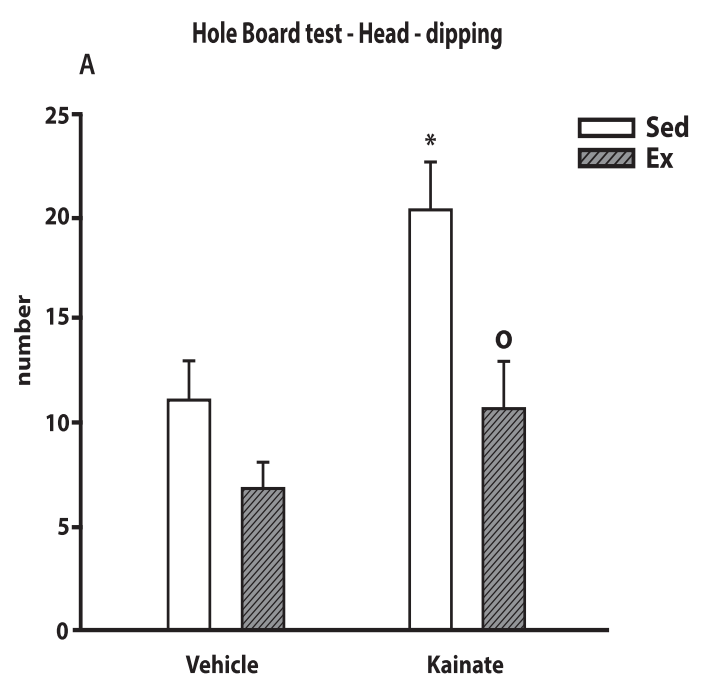

serum BDNF concentrations measured one month after SE (Fig. 4).

\section{DISCUSSION}

The present study has demonstrated that four weeks of endurance training at lactate threshold intensity is enough to increase physical working capacity of SHRs and corroborate with the recent findings that the intensity of maximal lactate steady state for the same time period increases the aerobic fitness of SHR assessed by increasing exercise intensity of maximal lactate steady state. ${ }^{11}$ Our findings show that endurance training at lactate threshold intensity has

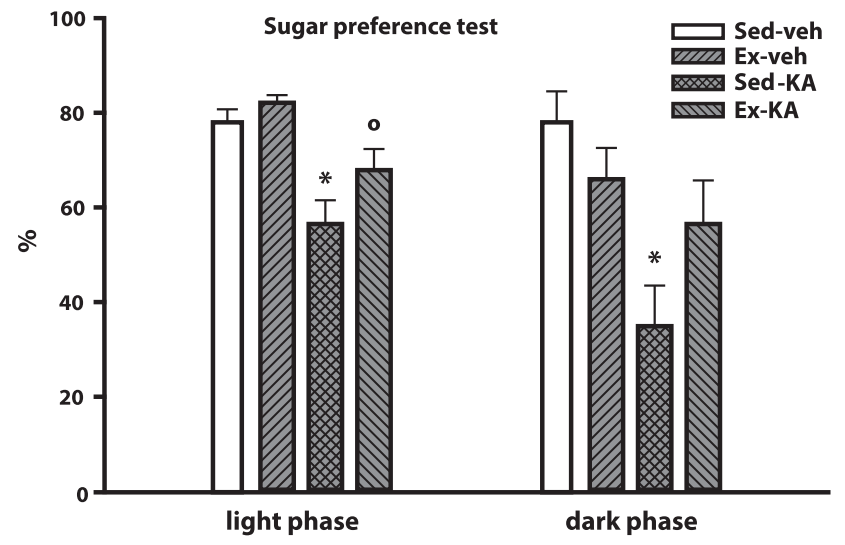

Figure 2. Effect of exercise prior to KA-induced SE on preference to sucrose in \% during a 12-hour period (light phase - 08:00-20:00 $\mathrm{h}$ and dark phase - 20:00-08:00 h) in Sed-veh, Ex-C, Sed-KA and Ex-KA group. Data are means \pm SEM $(n=9-13) . * p<0.05$ vs Sed-veh group, ${ }^{\circ} \mathrm{p}<0.05$ vs Sed-KA group.

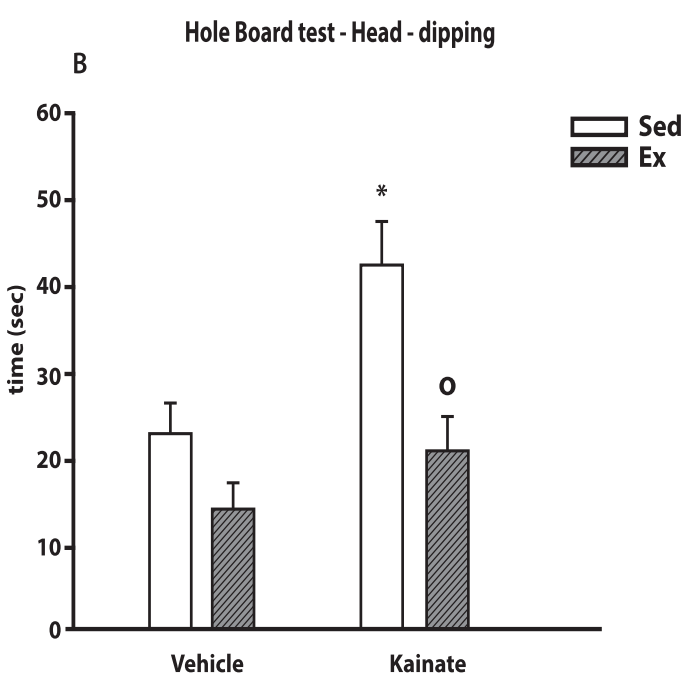

Figure 3. Effect of exercise prior to KA-induced SE on (A) number and (B) time of head-poking in Holeboard test in Sed-veh, Ex-C, Sed-KA and Ex-KA group. Data are means \pm SEM $(n=9-13) .{ }^{*} p<0.05$ vs Sed-veh group, ${ }^{\circ} \mathrm{p}<0.05$ vs Sed-KA group. 


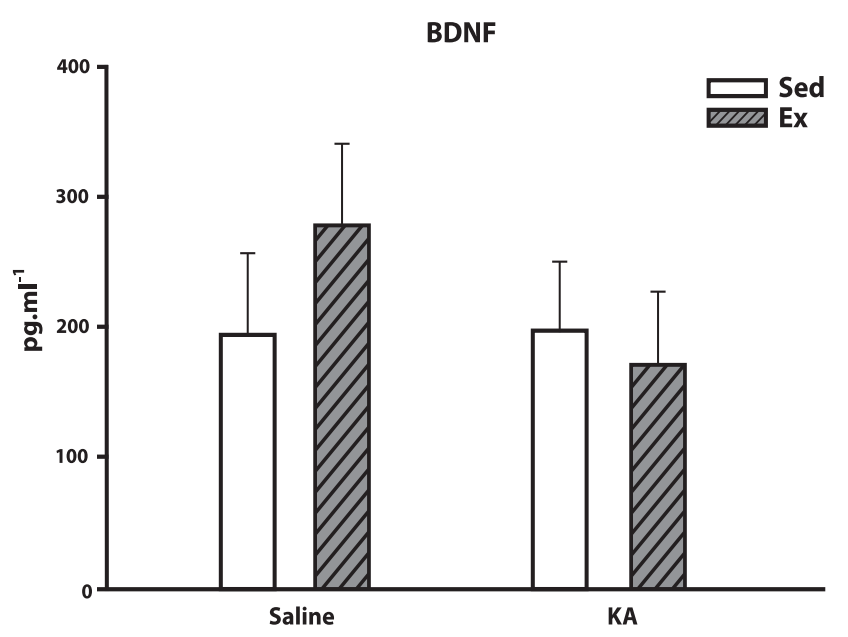

Figure 4. Serum concentration of BDNF (pg. $\mathrm{ml}^{-1}$ ) in experimental groups at the end of the experiment.

a beneficial effect on depression-like and impulsive behavior caused by SE in KA-treated SHRs. This positive influence might be due to improved physical working capacity in a co-morbid model of essential hypertension and status epilepticus. However, neither endurance training at lactate threshold intensity nor SE succeeded to change the serum BDNF concentrations. Accumulated experimental data have linked physical exercise to an increase in the brain BDNF expression. ${ }^{16}$ However, the exact role of BDNF factor in epileptogenesis is uncertain and reports revealed that while increased hippocampal BDNF could be pro-epileptogenic ${ }^{17,18}$, the neurotrophic factor may attenuate epilepsy ${ }^{18}$. The lack of changes in BDNF in the present study might be due to the fact that it was measured a month after the training period or because of the low training intensity. However, there are reports showing no change in the basal BDNF level in healthy subjects after a 5-week aerobic exercise training. ${ }^{19}$ Because there are no data on brain BDNF changes as a sequence of exercise and/or SE in SHRs it will be interesting to study further the concentration of this factor in epileptic brain after exercise.

The antidepressant effect of exercise has been recently reported in a rat model of co-morbid depression and epilepsy. ${ }^{20}$ The present findings are in agreement with Epps et al. ${ }^{20}$ and demonstrated that the beneficial effect of exercise program is associated with other positive outcomes, including cardiovascular, depression and impulsive behavior in a rat model of co-morbid hypertension and epilepsy.

\section{ACKNOWLEDGMENTS}

This work was supported by Medical University-
Plovdiv (Application Grant from MU-Plovdiv NO 04/2014).

\section{REFERENCES}

1. Graham DA, Rush JW. Exercise training improves aortic endothelium-dependent vasorelaxation and determinants of nitric oxide bioavailability in spontaneously hypertensive rats. J Appl Physiol 2004;96:2088-96.

2. Whelton SP, Chin A, Xin X, et al. Effect of aerobic exercise on blood pressure: a meta-analysis of randomized, controlled trials. Ann Intern Med 2002;136:493-503.

3. Gu Q, Wang B, Zhang XF, et al. Contribution of hydrogen sulfide and nitric oxide to exercise-induced attenuation of aortic remodeling and improvement of endothelial function in spontaneously hypertensive rats. Mol Cell Biochem 2013;375:199-206.

4. Delanty N, Vaughan C. Hypertension, and Posterior Leukoencephalopathy. In: Delanty N, Vaughan C. editors. Seizures Current Clinical Neurology. Springer Sci Business Media, New York 2002; pp 251-60.

5. Greenwood RS, Meeker R, Sullivan H, et al. Kindling in spontaneous hypertensive rats. Brain Res 1989;495:58-65.

6. Pietranera L, Saravia F, Deniselle MC, et al. Abnormalities of the hippocampus are similar in deoxycorticosterone acetate-salt hypertensive rats and spontaneously hypertensive rats. J Neuroendocrinol 2006;18:466-74.

7. Tchekalarova J, Pechlivanova D, Itzev D, et al. Diurnal rhythms of spontaneous recurrent seizures and behavioral alterations of Wistar and spontaneously hypertensive rats in kainate model of epilepsy. Epilepsy Behav 2010;17:23-32.

8. Tchekalarova J, Pechlivanova D, Atanasova T, et al. Diurnal variations of depressive-like behavior of Wistar and spontaneously hypertensive rats in kainate model of temporal lobe epilepsy. Epilepsy Behav 2011;20:277-285.

9. Tchekalarova J, Shishmanova M, Atanasova D, et al. Effect of endurance training on seizure susceptibility and behavioral changes after kainate-induced status epilepticus in spontaneously hypertensive rats. Brain Res 2015;1625:39-53.

10. Lambert M, Noakes TD. Spontaneous running increases VO2max, and running performance. J Appl Phiys 1990;68:400-3.

11. Petriz BA, Almeida JA, Gomes CP, et al. Exercise performed around MLSS decreases systolic blood pressure and increases aerobic fitness in hypertensive rats. BMC Physiol 2015;15:1.

12. Georgieva KN, Boyadjiev NP. Effects of nandro- 
lone decanoate on VO2max, running economy, and endurance in rats. Med Sci Sports Exerc 2004;36(8):1336-41.

13. Hellier JL, Partylo PR, Buckmaster PS, et al. Recurrent spontaneous motor seizures after repeated low-dose systemic treatment with kainate: assessment of a rat model of temporal lobe epilepsy. Epilepsy Res 1998;31:73-84.

14. Tchekalarova J, Ivanova N, Pechlivanova D, et al. Antiepileptogenic and neuroprotective effect of losartan in kainate model of temporal lobe epilepsy. Pharmacol Biochem Beh 2014;127:27-36.

15. File SE, Pellow S. The effects of triazolobenzodiazepines in two animal tests of anxiety and in the holeboard. Br J Pharmacol 1985;86(3):729-35.

16. Gomes FG, Gomes Da Silva S, Cavalheiro EA, et al. Beneficial influence of physical exercise follow- ing status epilepticus in the immature brain of rats. Neuroscience 2014;274:69-81.

17. Binder DK, Croll SD, Gall CM, et al. BDNF and epilepsy: too much of a good thing? Trends Neurosci 2001;24:47-53.

18. Simonato M, Tongiorgi E, Kokaia M. Angels and demons: neurotrophic factors and epilepsy. Trends Pharmacol Sci 2006;27:631-8.

19. Griffn EW, Mullally S, Foley C, et al. Aerobic exercise improves hippocampal function and increases BDNF in the serum of young adult males. Physiol Behav 2011;104:934-41.

20. Epps SA, Kahn, AB, Holmes PV, et al. Antidepressant and anticonvulsant effects of exercise in a rat model of epilepsy and depression comorbidity. Epilepsy Behav 2013;29:47-52.

\title{
Эффект тренировки при интенсивности нагрузки лактатного порога на максимальное время до истощения, депрессии и тревожного поведения спонтанно-гипертензивных крыс после эпилептического статуса, индуцированного каинатом
}

\author{
Катерина Н. Георгиева ${ }^{1}$, Маргарита С. Хаджиева ${ }^{1}$, Михаела С. Шишманова-Досева \\ Дора Д. Терзиева ${ }^{3}$, Никола Г. Георгиев ${ }^{4}$, Георги Г. Андреев ${ }^{4}$, Яна Д. Чекаларова ${ }^{5}$ \\ ${ }^{1}$ Кафедра физиологии, Медицинский университет- Пловдив, Болгария \\ 2 Кафедра фармакологии и лекарственной токсикологии, Медицинский университет- Пловдив, Болгария \\ ${ }^{3}$ Кафедра клинической лаборатории, Медицинский университет- Пловдив, Болгария \\ ${ }^{4}$ Медицинский факультет, Медицинский университет, Пловдив, Болгария \\ ${ }^{5}$ Институт нейробиологии, БАН, Болгария
}

\section{Адрес для корреспонденции: Катерина Н. Георгиева, Кафедра физиологии, Медицинский университет - Пловдив, бул. Васил Априлов 15A, 4002 \\ Пловдив, Болгария \\ E-mail:kng@plov.net \\ Тел.: +359898774527}

Дата получения: 16 октября 2015

Дата приемки: 21 июля 2016 Дата онлайн публикации: 29 ноября 2016

Дата публикации: 27 марта 2017

Ключевые слова: тренировка на бегущей дорожке, эпилептический статус, тревожность, SHRs

Образец цитирования: Georgieva KN, Hadjieva MS, Doseva MS, Terzieva DD, Georgiev NG, An-
Цель: Целью настоящей работы является исследование эффекта тренировочных занятий на бегущей дорожке при интенсивности нагрузки лактатного порога на максимальное время истощения (MTE) и сердечного ритма (CP) и поведенческих изменений после эпилептического статуса (ЭС), индуцированного каинатом (KA) у спонтанно-гипертензивных крыс (SHRs).

Методы: Мужские особи SHR были разделены на четыре группы: две, пребывающие в неподвижном состоянии (обработанные вехикулумом и КА) и соответственно две, подвергающиеся физической нагрузке (обработанные вехикулумом и КА). Тренированные крысы были подвергнуты бегу на бегущей дорожке со скоростью 20 м.мин ${ }^{-1}$ и $0^{\circ}$ повышения за 40 мин.д - $^{-1}$, за 4 wk. Максимальное время истощения и СР были измерены в начале и в конце периода тренировки. Эпилептический статус вызывается у половины неподвижных крыс и тренированных крыс путем серийного внутрибрюшинного введения КА в низких субконвульсивных дозах. Другая половина из групп получали физиологический раствор. Тест предпочтения сладкого раствора - сахарный тест (SPT) для определения депрессивного поведения и хол борд тест (HBT) для определения импульсивности были проведены через месяц после введения КА/вех.

Результаты: Максимальное время истощения было продлено у SHR в конце тренировочного периода по сравнению с началом. Вопреки этому, никакого влияния на сердечный ритм не было установлено у тренированных крыс. Ле- 
dreev GG, Tchekalarova JD. Effect of training at lactate threshold intensity on maximal time to exhaustion, depression and anxiety behaviour of spontaneously hypertensive rats after kainateinduced status epilepticus.

Folia Medica 2017;59(1):91-97.

doi: 10.1515/folmed-2017-0004 чение каинатом через месяц тренировок облегчило ангедонию, вызванную эпилепсией при SPT и соответственно стереотипное поведение при НBT.

Заключения: Взятые в совокупности, данные результаты свидетельствуют, что физические упражнения оказывают благотворное влияние на физическую дееспособность, депрессию и импульсивное поведение в коморбидной модели эссенциальной гипертонии и ЭС. 